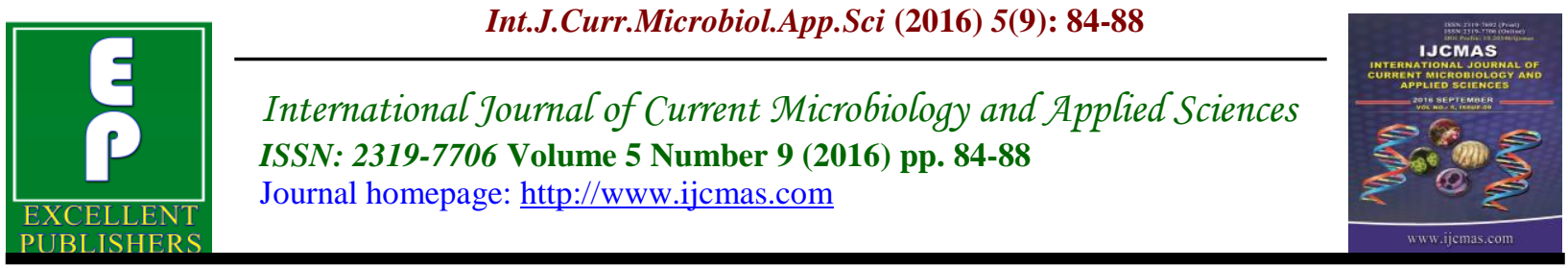

Original Research Article

http://dx.doi.org/10.20546/ijcmas.2016.509.010

\title{
Seroprevalance of Viral Hepatitis in a Tertiary care Hospital in North India
}

\author{
Shivani Satia* \\ Lady Hardinge Medical College and Associated Hospitals, India \\ *Corresponding author
}

\section{Keywords}

Seroprevalence, Hepatitis A, Hepatitis B, Viral Hepatitis.

Article Info

Accepted:

10 August 2016

Available Online:

10 September 2016

\section{A B S T R A C T}

Hepatitis is an inflammation of the liver, most commonly caused by a viral infection. In recent years India and other transitional economies are showing a significant epidemiological shift of HAV infection from high endemicity to intermediate endemicity. Approximately 240 million people are chronically infected with HBV worldwide, while 150 million people are infected with $\mathrm{HCV}$ There is a need for study of these etiological agents in jaundice for appropriate management as well as prevention of viral hepatitis. The aim of the present study was to evaluate seroprevalence of viral hepatitis A, B and C and E in patients presenting with viral Hepatitis. The study population comprised of 9263 patients presenting with acute hepatitis. Samples were collected from patients with clinically suspected acute infectious hepatitis at Hospital. Serum samples were collected Seroprevalence rate was calculated and stratified by age. Out of the 9263 adults with acute viral hepatitis studied, HAV was found to be the most common etiological agent (12.3\%), followed by HEV (4.97\%), HBV (3.54\%) and HCV $(2.08 \%)$. Co-infections with more than one virus were present in 7 cases; HBV-HCV co-infection being the most common.

\section{Introduction}

Hepatitis is an inflammation of the liver, most commonly caused by viral infections. Hepatitis A and Hepatitis E virus (HEV) is considered a major etiological agent of enterically-transmitted viral hepatitis.

Hepatitis A infection is endemic in less developed countries, although a decrease in its prevalence has been observed recently in areas where sanitary conditions have been improving (de Paula et al., 2001). Hepatitis $B$ virus (HBV) is transmitted by parenteral, vertical and sexual routes, whereas hepatitis $\mathrm{C}$ virus(HCV) is usually transmitted by transfusion (de Paula et al., 2001; Acharya et al., 2006).

All types of viral hepatitis produce clinically similar illness. These range from asymptomatic and inapparent to fulminate and acute fatal infections on one hand, and from subclinical persistent infections to rapidly progressive chronic liver disease with cirrhosis and hepatocellular carcinoma (Mohana Lakshmia et al., 2011) on the other. 
Areas of the world can be characterized as having high, intermediate and low endemicity for hepatitis A. In recent years India and other transitional economies are showing a significant epidemiological shift of HAV infection from high endemicity to intermediate endemicity (Elisabetta Franco et al., 2012).

According to the World Health Organisation (WHO), approximately 240 million people are chronically infected with HBV worldwide, while 150 million people are infected with HCV (Rachna Behal et al., 2008).

There is a need for study of these etiological agents in jaundice for appropriate management as well as prevention of viral hepatitis. Since there is paucity of data regarding seroprevalence of viral hepatitis in North India therefore, this study was undertaken to determine the prevalence of hepatotropic viruses among patients presenting with viral hepatitis.

\section{Materials and Methods}

This prospective study was conducted in the Department of Microbiology at Lady Hardinge Medical College, which is a tertiary care hospital in Northern India, from January 2013 to August 2015. Samples were collected from patients with clinically suspected acute infectious hepatitis at Hospital. Serum samples were collected from 9263 patients.

The material collected was whole blood using sterile disposable syringes under aseptic precautions. $5 \mathrm{ml}$ of blood was withdrawn by venepuncture, and it was collected in a sterile test tube without adding any anticoagulant. Serum was separated and stored at $-20^{\circ} \mathrm{C}$ until tested. The serum samples were tested by using ELISA Kits for the following viral markers.

Hepatitis B virus surface antigen (Biorad ELISA HbsAg)

IgM antibodies to Hepatitis A virus. (DRG Diagnostics HAV IgM).

IgM antibodies to Hepatitis $\mathrm{E}$ virus. (MBS SRL HEV IgM).

Antibody Hepatitis C virus. (Biorad ELISA Anti HCV

The optical density (OD value) value was taken in ELISA reader and cut off value was calculated as per manufacturers guidelines. All serum samples having antibody index above 1.1 were considered positive and those below 0.9 were taken as negative.

\section{Results and Discussion}

A total of 9263 patients were evaluated. Of the 9263 patients, 1906 were children, and 7357 were adults. Table 1 refers to the general characterization of the sample, with the population distribution according to age.

Out of 9263 patients, viral aetiology was confirmed in $622(6.7 \%)$ cases while in 8641 $(93.2 \%)$ cases no hepatitis virus could be detected. Hepatitis A virus was found in the maximum number of cases (12.3\%), followed by $\mathrm{HEV}$ (4.97\%), HBV (3.54\%) and $\mathrm{HCV}(2.08 \%)$.

Table 2 compares seroprevalence of viral hepatitis in children and adults.In children hepatitis A showed the highest seroprevalence $(31.92 \%)$ followed by HBV $(4.09 \%)$ while in adults hepatitis $\mathrm{E}$ had the highest seroprevalence $(6.5 \%)$, followed by HBV $(4.03 \%)$ and HCV (2.13\%).

Table 3 shows the age-specific prevalence of 
parenterally-transmitted hepatitis viruses (HBV and HCV). There was a strong trend for increasing $\mathrm{HBV}$ infection rate with increasing age. High rates of $\mathrm{HBV}$ infection were seen in 51-60 years $(9.32 \%)$ and above 60 years $(14.1 \%)$. The age-specific seroprevalence of $\mathrm{HCV}$ increased with age, with the highest prevalence at the above 60 years $(8.39 \%)$ followed by 51-60 years $(1.3 \%)$ and $1-10$ years $(1.3 \%)$ respectively.

Highest prevalence of HAV and HEV was seen in the age group of 1-10years $(39.62 \%)$ and 21-30 years respectively. Infection with more than one virus was detected in 7 cases, the most common being $\mathrm{HBS}$ and $\mathrm{HCV}$ co-infection in 3 cases. Co-infection of HEV with other viruses was present in 3 cases (1 case of HEV with HCV and 2 cases of HEV with HAV).

The present study was conducted to evaluate the seroprevalence of Hepatitis A, B, C and $\mathrm{E}$ viral markers among children and adults. In our study, HAV (12.3\%) was identified to be the most common cause of acute hepatitis followed by HEV (4.9\%), HBV (3.54\%) and HCV $(2.08 \%)$. Similar finding have been reported by P. Jain (Jain et al., 2013) HAV $(26.96 \%)$ was identified as the most common cause of acute hepatitis followed by HEV (17.97\%), HBV (16.10\%) and HCV (11.98\%).

In our study Hepatitis A virus was commonest etiological agent in children (31.9\%) whereas HEV (6.3\%) was the commonest etiological agent among adults. In other studies Lakshmi et al., (2011) from South India reported seroprevalence of HBV as the commonest cause of viral hepatitis in adults followed by HEV (29.8\%). In our study prevalence of Hepatitis A in children was found to be $40.5 \%$. whereas Tandon (Tandonet al., 1984) and panda (Prakash et al., 1998) reported higher incidence of hepatitis $\mathrm{A}$ in children, $67 \%$ and $55.8 \%$ respectively. Kazemi (Seyed et al., 2007) et $a l$, in Iran reported high incidence of HAV $44.3 \%$ in children. The high prevalence rate of hepatitis $\mathrm{A}$ in children is attributed to their susceptibilities to infection due to poor hygiene, overcrowding and poor sanitary conditions, when there is abundant shedding of HAV in the faeces.

Seroprevalence of hepatitis B virus infection is low in our study (3.54\%) when compared to other studies by $P$. Jain $26.96 \%{ }^{6}$. LiviaMelo Villar (LiviaMelo et al., 2014) from Brazil reported HBV infection $1.8 \%$, Karatekin et al., from Turkey reported 3.8\%. Wanga B reported the overall seroprevalence of HBV $6.1 \%$.

In age wise incidence lowest seroprevalence of Hepatitis B was seen in 0-1years age group which indirectly indicates the low incidence of vertical transmission of hepatitis B infection. The successful introduction of the HBV vaccine into the National Immunization Program in India has had a great impact on the prevalence of HBV markers among children. The results of the present study showed that universal vaccination of infants has contributed directly to the reduction in the prevalence of HBV.

The peak prevalence of hepatitis B and Hepatitis $\mathrm{C}$ was observed in the older age groups, above 50 yrs. Higher prevalence in older age groups may be attributed to iatrogenic factors including vaccinations by the use of unsterilized kits, transfusion of unscreened blood, and etc. Further the trend of immunization against hepatitis-B has been introduced in the recent few years. Therefore the older age group population having a higher prevalence of HBs Ag de in our study is presumptively due to lack of immunization against the disease in their time. 
Table.1 Number of patients in different age groups

\begin{tabular}{|l|l|}
\hline Age group & No. of patients \\
\hline $0-1 \mathrm{yr}$ & $153(0.99 \%)$ \\
\hline $1-10 \mathrm{yrs}$ & $874(7.4 \%)$ \\
\hline $11-20 \mathrm{yrs}$ & $879(22.3 \%)$ \\
\hline $21-30 \mathrm{yrs}$ & $4027(46.7 \%)$ \\
\hline $31-40 \mathrm{yrs}$ & $1885(20.3 \%)$ \\
\hline $41-50 \mathrm{yrs}$ & $829(8.9 \%)$ \\
\hline $51-60 \mathrm{yrs}$ & $354(3.8 \%)$ \\
\hline Above 60 yrs & $262(2.8 \%)$ \\
\hline Total & 9263 \\
\hline
\end{tabular}

Table.2 Seroprevalence of viral hepatitis in children and adults

\begin{tabular}{|l|l|l|}
\hline Viral Hepattis & Children & Adults \\
\hline HBV & $4.09 \%$ & $4.03 \%$ \\
\hline HCV & $1.8 \%$ & $2.13 \%$ \\
\hline HAV & $31.9 \%$ & $4.43 \%$ \\
\hline HEV & $1.2 \%$ & $6.3 \%$ \\
\hline
\end{tabular}

Table.3 Seroprevalence of Hepatitis B and Hepatitis C in different age groups

\begin{tabular}{|l|l|l|l|}
\hline Age group & $\begin{array}{l}\text { Total no. of } \\
\text { patients }\end{array}$ & HBV & HCV \\
\hline $0-1 \mathrm{yr}$ & 153 & $2(1.3 \%)$ & $4(2.6 \%)$ \\
\hline $1-10 \mathrm{yr}$ & 874 & $28(3.2 \%)$ & $12(1.3 \%)$ \\
\hline $11-20 \mathrm{yr}$ & 879 & $48(5.4 \%)$ & $20(2.2 \%)$ \\
\hline $21-30 \mathrm{yr}$ & 4027 & $142(3.5 \%)$ & $67(1.66 \%)$ \\
\hline $31-40 \mathrm{yr}$ & 1885 & $63(3.34 \%)$ & $35(1.85 \%)$ \\
\hline $41-50 \mathrm{yr}$ & 829 & $22(2.65 \%)$ & $12(1.4 \%)$ \\
\hline $51-60 \mathrm{yr}$ & 354 & $33(9.32 \%)$ & $21(5.9 \%)$ \\
\hline Above $60 \mathrm{yr}$ & 262 & $37(14.1 \%)$ & $22(8.39 \%)$ \\
\hline Total & 9263 & $328(3.54 \%)$ & $193(2.08 \%)$ \\
\hline
\end{tabular}

In our study seroprevalence of $\mathrm{HCV}$ was low $(2.08 \%)$ in children and adults. Jain $e t$ al., reported a high prevalence of $\mathrm{HCV}$ was seen in both children (6.29\%) and adults (18.54\%). Mushtaq et al., (2009) from Aligarh reported low seroprevalence of $\mathrm{HCV}$ in children $(2.03 \%)$

In conclusion, viral hepatitis is a significant problem in North India. The high incidence of $\mathrm{HAV}$ in children shows that there is a need for proper sanitation and including hygienic food habits. Health education of parents is also necessary to control these infections in children. Our present study indicates vaccination of adults against hepatitis B virus has led to decrease in the incidence of hepatitis B.

\section{References}

Acharya, S.K., Kaushal Madan, S., 
Dattagupta, S.K., Panda. 2006. Viral Hepatitis In India. The National Med. J. India, 19(4).

de Paula, V.S., M.E. Arruda, C.L. Vitral, A.M.C. Gaspar. 2001. Seroprevalence of Viral Hepatitis in Riverine Communities from the Western Region of the Brazilian Amazon Basin Mem Inst Oswaldo Cruz, Rio de Janeiro, 96(8): 000-000, November 2001112344.

Elisabetta Franco, Cristina Meleleo, Laura Serino, Debora Sorbara, Laura Zaratti. 2012. Hepatitis A: Epidemiology and prevention in developing countries. World J. Hepatol., 4(3): 68-73.

Jain, P., S. Prakash, S. Gupta, K.P. Singh, S. Shrivastava, D.D. Singh, J. Singh, A. Jain. 2013. Prevalence of hepatitis A virus, hepatitis $\mathrm{B}$ virus, hepatitis $\mathrm{C}$ virus, hepatitis D virus and hepatitis $\mathrm{E}$ virus as causes of acute viral hepatitis in North India: A hospital based study. Indian J. Med. Microbiol., 31(3): 261265.

LiviaMelo Villar, Luciane Almeida Amado, Adilson José de Almeida,Vanessa Salete de Paula, Lia Laura LewisXimenez, and Elisabeth Lampe. Low Prevalence of Hepatitis B and C Virus Markers among Children and Adolescents. BioMed. Res. Int., Volume 2014, Article ID 324638.

Mohana Lakshmia, T., A., Vaithilingamb,
A., Franklina, E., Prabhakar Reddy. 2011. The prevalence of serological markers of viruses causing acute hepatitis in south indian population. Int. J. Biol. Med. Res., 2(4): 925 - 928. Mudasir Mushtaq, Seema Alam, Indu Shukla, Rana Sherwani, S., Manazir Ali Prevalence of Hepatitis C virus infection among children with liver disease, 13(1): 1-12.

Prakash, J., C., Panda, R., Bora, D., Jain, D.C., Datta, K.K. 1998. Acute sporadic viral hepatitis in urban population of a tribal district in MadhyaPradesh. Indian Pediatr., 35(2): 105-109.

Rachna Behal, Renu Jain, Krishan, K., Behal, Ajay Bhagoliwal, Nakshatra Aggarwal and T.N. Dhole. 2008. Seroprevalence And Risk Factors For Hepatitis-B Virus Infection Among General Population In Northern India. Arq. Gastroenterol., 45(2).

Seyed Alinaghi Kazemi, Manoochehr Mahram, Ali Koosha Hamid Reza Amirmoghaddami. 2007. Seroprevalence of Hepatitis A in 7-10 Year-old Children. Iran J. Ped., 17(1).

Tandon Gupta, H., Irshad, M., Joshi, Y.K., Chawla, T.C. 1984. Associated infection with non-A, non-B virus as possible cause of liver failure in Indian HBV carriers. Lancet, 29; 2(8405): 750-751.

\section{How to cite this article:}

Shivani Satia. 2016. Seroprevalance of Viral Hepatitis in a Tertiary care Hospital in North India. Int.J.Curr.Microbiol.App.Sci. 5(8): 84-88.

doi: http://dx.doi.org/10.20546/ijcmas.2016.509.010 